\title{
An In-Depth Look at Economic Growth and Employment in Post-Apartheid South Africa: Analysis and Policy Implications
}

\author{
Wiza Munyeka \\ Department of Business Management, University of Limpopo (Turf loop Campus), \\ Private Bag X 1106. Sovenga, 0727. South Africa \\ Email address: masterwiza2000@yahoo.com
}

\section{Doi:10.5901/jesr.2014.v4n3p245}

\section{Abstract}

The purpose of this study was to determine the relationship of economic growth and employment in post-apartheid South Africa and to conclude by providing an analysis of macroeconomic policies for that period. A correlational research was conducted to investigate whether the relationship exists in South Africa and also the nature of the relationship. An employment elasticity of growth model was employed to a sample size of 18 (number of years). The findings revealed that employment has, to a lesser extent, been responsive to economic growth for most of the period. Thus, employment elasticity of growth has been inelastic. This implies that a percentage change in economic growth has been accompanied by a change of less than one percentage in employment. The study found that the Accelerated Shared Growth Initiative for South Africa (ASGISA) has outperformed other policies in relation to economic growth and employment targets. It concludes that higher percentage increase in economic growth may lead to an increase in employment. The study has highlighted areas of possible job creation opportunities. On policy perspective, it concludes that the adoption of New Growth Path and National Development Plan while ASGISA is still in process will require a strong coordination and dedication of many state resources.

KEYWORDS: Accelerated Shared Growth Initiative for South Africa (ASGISA) Economic Growth; Employment; Growth, Employment, and Redistribution (GEAR); Post-Apartheid South Africa; Policy; Reconstruction and Development Programme (RDP) New Growth Path; National Development Plan;

\section{Introduction}

Over the few past decades, the primary focus of world economic attention has been on measures to accelerate the growth of national incomes. Economists and politicians alike, from all nations, rich and poor, capitalist, socialist and mixed, have worshipped the shrine of economic growth (Todaro, 1992). Governments have been seen to be increasingly constrained in terms of the actions that they are able to take which promote growth or regulate the ways in which the beliefs of growth are distributed. An inherent belief behind this approach has been that the benefits of growth would reach the poor through a trickledown effect (May, 2000).

Furthermore, most economists would agree that the creation of jobs is the most important objective of economic policy in any country. To keep unemployment as low as possible, jobs must be created at a sufficient rate (Mohr and Fourie, 2008). Sustained growth with employment generating policies eventually trims down the critical problem of unemployment (Hussain, Hussain, Siddiqi and Iqbal, 2010). Economic growth depends on productivity improvements and the functioning of labour markets, but well-functioning labour markets rest in turn on a sustained and stable path of economic growth (OECD, 2011).

South Africa was a growth machine in the 1960s, after which followed a long period of stagnation with sanctions and the apartheid struggle, followed by a slow growth after the political transformation (Rattso and Stokke, 2007). The transformation that South Africa has undergone since its democratic transition in 1994 is nothing short of remarkable (Rodrik, 2006). This democratic transition created expectations of a significant turnaround in the economic performance. Trade and financial sanctions and internal political opposition to the apartheid government had contributed to the poorest ten-year growth performance since the Second World War and the removal of these constraints was widely expected to transform the country's economic performance (De Wet, 1995; Du Plessis and Smit, 2007).

It would be naïve to believe that democracy in itself will solve all South Africa's problems. In fact, it may exacerbate them through increased expectations. The legacy of apartheid lives on and will continue to do so (Luiz, 1996). It has been upon the ANC-led government to drive the economy away from apartheid. 


\section{Problem Statement}

The most pressing problem facing South Africa today is the absence of sustained economic growth and job creation, which are essential to reduce poverty and improve living conditions (Lewis, 2002). Tackling South Africa's dilemma of low economic growth and worsening unemployment is a formidable challenge (Mahedea and Simson, 2010).

Using an expanded (higher) or narrow (lower) definition, unemployment rates in South Africa are exceptionally high (Luyt, 2008).

South Africa faces the harsh reality that not enough people work. Out of a population of some 50 million people, there are only 13.1 million employed. Poverty, inequality and social inequities stem from the exclusion of the majority from labour market. Higher employment and economic participation would make progress in reducing poverty and income inequality in South Africa. South Africa's employment ratio is currently 40.8 per cent; this means that just two-outof-five working age South Africans (aged between 15 and 64) has a job. The employment ratio is very low by international standards. There are currently 4.1 million unemployed workers; one in four of those available to work do not have a job. About 2.8 million are long-term unemployed and a further 2.2 million are discouraged. South Africa's unemployment rate of 24 per cent is among the highest in the world and rises to 32.4 per cent if discouraged workers are included. Despite making up just 0.5 per cent of the global labour force, South Africa accounts for 2 per cent of global unemployment (National Treasury, 2011).

South Africa is one of the world's most unequal societies. Inclusive growth and poverty reduction necessitates much faster and sustained economic growth and labour absorption.

\section{Objectives of the Study}

- To analyze South Africa's economic growth from 1994 to 2012

- To analyze South Africa's employment from 1994 to 2012.

- To determine the relationship between economic growth and employment in South Africa from 1994 to 2012.

- To analyze the major macroeconomic policies (GEAR, ASGISA, New Growth Path and New Development Plan) in terms of targets and outcomes of both economic growth and employment.

- To formulate suggestions and recommendations arising from the analysis.

\section{Research Questions}

- What have been the major sources of South Africa's economic growth since 1994?

- Which sector can contribute largely to job creation in South Africa?

- Is an annual increase of 5.4\% economic growth (as in the New Development Plan) enough to solve South Africa's of unemployment?

- What is the employment intensity of growth in South Africa?

- Are there any similarities among GEAR, ASGISA, New Growth Path and New Development Plan? If YES, wouldn't that hamper the progress of New Development Plan in terms of economic growth and employment targets?

- What are the possible areas for improving employment growth in South Africa?

\section{Literature Review: Growth, Employment and Their Relationship}

\subsection{Economic growth}

Klein (2011) provided an assessment of the South African potential output growth for the period $1985-2010$ by applying both structural and nonstructural techniques. The analysis suggests that, while potential output growth steadily accelerated in the post-apartheid era to about 3, 5 percent (1994 - 2008), it has decelerated considerably following the outbreak of the financial crisis, as was observed in other advanced and emerging economies. While this indicates that, at around -1.5 percent, the estimated 2010 output gap was lower than previously thought, there is a fair amount of uncertainty regarding its "true" magnitude, reflecting in part the backward looking nature of the estimation methods. He is of the view that the potential growth is likely to gradually revert to its pre-crisis pace and the output gap to have closed by early 2012. 
Sen and Kirkpatrick (2009) used a diagnostics approach to economic growth and employment in Kosovo. It was found that economic growth has been below the rate achieved in neighboring countries and more than one-third of the work force is unemployed. The paper applies a 'diagnostics' analytical framework to identify the most biding constraints on economic growth and job creation. The biding constraints to growth are found to be the costs and access to finance, poor provision of public goods and weaknesses in the rule of law. The analysis also suggests that policy options for job creation must focus on increasing both economic growth and the employment intensity of growth.

Rangasamy (2008) says economic policy has always accorded an important role to export production in the overall growth process in South Africa. Recent policy proposals once again affirm this commitment. He attempted to ascertain whether the emphasis on export production is justified. Using modern econometric techniques within a multivariate framework, the results show that there is uni-directional Granger-causality running from exports to economic growth in South Africa. In addition, the gross domestic product (GDP) accounting identity underestimates the contribution of exports to economic growth. Thus, deliberate policy measures that stimulate export production will greatly enhance the growth process for the South African economy. The results indicate that more attention should be given to the promotion of non-primary exports.

Du Plessis and Smit (2007) used a growth accounting model and it revealed the important role of multifactor productivity in South Africa's economic growth performance over the past two decades. In the ten years after 1994, productivity growth was the major factor in the growth revival, which contrasts sharply with the negative contribution to growth by productivity in the ten years before 1994. Though modest the contribution of capital to growth was slightly higher since 1994 than in the preceding decade, while labour's contribution declined though it remained positive. Fifty percent or more of South Africa's subsequent economic recovery can be attributed to total factor productivity growth. With very few exceptions this aggregate level result also holds at the level of sectors and sub-sectors in South Africa. While it is difficult to account for this recovery in productivity growth, the most compelling evidence reported here finds the economy's increasing openness to international trade to be the leading cause of rising productivity locally. In summary, the evidence offered here suggests that it was openness (to trade and capital flows), lower uncertainty and lower interest rates that explain South Africa's growth recovery since 1994.

On economic growth, Millin and Nichola (2005) used Kaldorian growth theory and found that manufacturing growth can be considered as an engine of GDP growth in South Africa. The faster the rate of growth in manufacturing, the faster the overall rate of productivity growth in South Africa as more labour used in the manufacturing sector does not necessarily detract from growth elsewhere in the South African economy.

\subsubsection{Employment}

Berument, Dogan and Tansel (2008) investigated how macroeconomic policy shocks in Turkey affect the total unemployment and provide evidence on the differential responses of the unemployment by sectors of economic activity. The paper considers not only the response of total unemployment but also the response of unemployment by sectors of economic activity. It considers not only the effect of monetary policy shocks, but also the effects of several other macroeconomic shocks. The quarterly data used which covers the period 1988:01 to 2004:04 from Turkey. A VAR model with a recursive order is employed to estimate the effects of shocks in real GDP, price, exchange rate, interbank interest rate, money supply and own sectorial unemployment on unemployment sectors of economic activity. The results indicate that the positive income shock is followed by a decrease in unemployment in all economic activity groups during the initial periods except the unemployment in the Electricity sector and the Community Services sector.

Coming back to South Africa, Banarjee, Galiani, Levinsohn, McLaren and Woolard (2006) documented the rise in unemployment in South Africa since the transition in 1994. They described the likely causes of this increase and analyzed whether the increase in unemployment is due to structural changes in the economy (resulting in new equilibrium unemployment rate) or to negative shocks (that temporarily have increased unemployment). They concluded the former are more important. Their analysis included a multinomial logit approach to understand transitions in individual-level changes in labour market status using the first nationally representative panel in South Africa. The analysis highlighted several key constraints to addressing unemployment in South Africa.

\subsubsection{The relationship between economic growth and employment}

Sodipe and Ogunrinola (2011) examined the employment and economic growth relationships in the Nigerian economy. A simple model of employment was formulated and estimated using Ordinary Least Squares technique before and after the 
time series data used for the study were corrected for non-stationarity using Hodrick-Prescott filter. The result of the econometric analysis shows that a positive and statistically significant relationship exists between employment level and economic growth in Nigeria while a negative relationship was observed between employment growth rate and the GDP growth rate in the economy. They conclude by advocating for increased labour-promoting investment strategies that will help to reduce the high current open unemployment in Nigeria.

Ajilore and Yinusa (2011) explored the employment intensity of sectorial output growth in Botswana with a view to identifying key sectors of Botswana economy that are employment intensive. The study used both simple elasticities and econometric procedures to provide empirical evidence concerning the extent to which economic growth that has occurred in Botswana is employment intensive and in which sectors. The findings confirmed the low labour absorptive capacity of the Botswana economy at the aggregate and at sectorial decompositions, suggesting the notion that growth performance in the country is, after all, 'jobless growth'. With respect to policy, the study recommends a successful mineral-led economy that is able to diversify into sectors and activities that are by nature relatively more labour-intensive.

Mahadea and Simson (2010) initially examined the problem of low employment economic growth performance for the period 1994 - 2008 by drawing on the Harrod-Domar model and then over a longer time period by using regression analysis. The study used a parsimonious regression model to highlight the probable links between changes in economic growth and changes in employment. The study found that the growth elasticity of employment over the $1994-2008$ periods is low and over time horizon the marginal growth employment effect is weak. What is found, though not cast in stone, is instructive that the size impact of growth on marginal employment is positive and less than proportionate.

Garett and Rhine (2010) extend the earlier models of economic growth and development by exploring the effect of economic freedom on U.S. state employment growth. They find that states with greater economic freedom - defined as the protection of private property and private markets operating with minimal government interference - experienced greater rates of employment growth. In addition, we find that less restrictive state and national government labour market policies have greatest impact on employment growth in U.S. states. Except for labour market policies, they find that state employment growth is influenced by state and local government policies, but not the policies of all levels of government, including the national government. The results suggest that policy-makers concerned with employment should seriously consider the degree to which their own labour market polices, as well as those of the national government, may be limiting economic growth and development in their respective states.

Seyfried and College (2008) examined the relationship between economic growth and employment in the six developed nations from 1990 to 2006. Models were developed to estimate the employment elasticity of economic growth within each nation. Among those for whom a significant relationship was found, employment intensity is estimated to range from 0.14 to 0.33 . Once the model is augmented to account for persistence in employment growth, employment intensity diminished in a majority of the nations, but remained significant in most, ranging from 0.16 to 0.33 . The model was further modified to examine the dynamic nature of the relationship between employment and economic growth using impulse response analysis. As before, differences in the responsiveness of employment to economic growth are found between the nations studied. Reasons for the differences in the employment elasticity of economic growth between nations are discussed. Evidence is found suggesting that nations with high labour force growth rates and/or relatively large service sectors tend to exhibit higher levels of employment intensity of economic growth.

Dumitrescu, Dedu and Enciu (2009) described the correlation between unemployment and real GDP growth in Romania. They found that if unemployment is below its natural level, economic growth will generate higher inflation. The empirical analysis showed that a rise of one percentage point of unemployment is associated with a decline of roughly half percentage point of real GDP growth. If GDP growth rate is below its natural rate it is indicated to promote employment because this rise in total income will not generate inflationary pressures. In contrast, if the GDP growth is above its natural level, policy makers will decide not to intensively promote the creation of new jobs in order to obtain a sustainable growth rate which will not generate inflation. They found that the variables are negatively correlated.

Phelps (2008) investigates if immigration impacts the American economy, its GDP and the unemployment rate. $\mathrm{He}$ finds that immigration has added to the overall GDP and has aided in small amounts to the economic growth. Immigrants are adding more prestige to America through their scholastic accomplishments as well. However, the foreign born population is impacting America in negative ways also. Immigration has brought down wage rates for low paying jobs and has increased the unemployment rate for that select group of native born workers.

Momete (2007) analyzed the relationship between employment and economic growth in Romania using employment coefficient. He found that Romanian economic growth registered high scores during the last years, but this was coupled with low employment levels and even labour shortages in certain sectors. The number of employed persons in the primary sector recorded high values, Romania being the "leader" among the EU-27, with the highest percent of 
population involved in agriculture. Moreover, Romania has a shortage of employed persons with tertiary education, this being a result of the present structure of the national economy. Additionally, negative employment elasticities of growth were registered over the last 10 years, and are to be expected on the long run.

Siphambe (2007) found that Botswana has experienced a spectacular economic growth since gaining independence in 1966. While the foundation of its growth lies in the country's mineral wealth, he argues that public expenditure has been the main conduit to channel mining revenues back into the economy. This, together with a strong capacity of the Botswana government to formulate and implement coherent national policies through various National Development Plans, has been the main factor behind its good growth performance. However, in terms of employment creation the picture is more nuanced: while formal sector employment grew by almost in line with GDP until 1991, employment growth de-linked from output growth in the early 1990s and fell behind population growth. As the paper details, this de-linking between growth and employment coincided with a number of policy reforms that where intended to deregulate the Botswana economy. The analysis of macroeconomic policies is complemented by discussion of Botswana's labour market policies, especially with respect to wage-setting, industrial relations and skills development, and their mutual coherence.

Tregenna (2007) investigated the relationship between the manufacturing and services sectors in South Africa and between each of them and the rest of the economy, in terms of capacity to drive and support economic growth and employment retention and creation. A key question in this regard is whether manufacturing (still) has the potential to be the key engine of economic growth, or whether services or services subsectors can play this role in future. This has critical implications for whether the relative decline in manufacturing and rise in services in the South African economy will affect the prospects for sustainable growth and for addressing the crisis of unemployment. International comparisons reveal that while the share of manufacturing value added in South Africa is high for our level of income, the share of manufacturing employment is less than would be expected. Meanwhile, the shares of GDP and services employment are both higher in South Africa than would be expected based on international patterns.

\section{Review on Post-Apartheid Macroeconomic Policies in Relation to Growth-Employment Targets and Outcomes}

South Africa's growth performance since 1994 demonstrates that macro stability is not enough. Prudent fiscal and monetary policies are necessary, but certainly not sufficient, to generate sustained growth. While non-single sector or individual policy change can provide a "quick fix" to the growth problem, there are a number of policy areas in which change could begin to create forward progress and create further momentum for change (Lewis, 2002).

The global economic crisis has demonstrated that the old patterns of growth, income distribution, regulation and governance do not meet the needs of the world economy. The growing weight of China and India in international trade signals a change in the global economic balance. These considerations are informing policy development and new approaches in South Africa. There is renewed determination in government to build on past successes, to be honest about our weaknesses and to achieve better results. Our high levels of poverty and unemployment throw into sharp relief the need to transform our economy (National Treasury, 2010).

The impact of macroeconomic policies on growth, employment creation and poverty reduction is likely to be stronger when they are part of a wider effort to marshal resources for accelerated development (Bradford, 2005).

\subsection{RDP}

Faced with the enormous challenges, the new South African government African National Congress (ANC) introduced the Reconstruction and Development Programme in 1994, self-described as an integrated, coherent socio-economic framework (Hoogeveen and Ozler, 2005). It proposed growth and development through reconstruction and redistribution, sought a leading and enabling role for government in guiding the mixed economy through reconstruction and development, and it argued for a living wage as a pre-requisite for achieving the required level of economic growth. The systematically deprived majority supported the RDP as it promised a democratic society that will embark on unleashing the economic potential of the country in order to provide jobs, more equitable distribution of income and wealth, and provision of basic needs for all South Africans (Adelzadeh, 2006). 


\subsection{GEAR}

The Growth, Employment, and Redistribution (GEAR) programme of 1996, which represented a formal macroeconomic framework for growth, followed the RDP and aimed to increase growth and stimulate job creation (Hoogeveen and Ozler, 2005). The ANC government implemented an orthodox macroeconomic policy (GEAR) which stressed deficit reduction and a tight monetary policy, combined with trade liberalization (Weeks, 1999). GEAR aimed at strengthening economic development, broadening employment and redistributing income and socioeconomic opportunities in favor of the poor. The key goals of the policy as originally outlined were economic growth of $6 \%$ in the year 2000 , inflation of less than $10 \%$, employment growth above the increase in economically active population, reduction of the deficit on the current account and the balance of payments to between $2 \%$ and $3 \%$, and reduction of the budget deficit to below $4 \%$ of GDP (Knight, 2006).

\subsection{ASGI-SA}

Accelerated Shared Growth Initiative for South Africa (ASGISA) is distinguished, relatively to its two predecessors, GEAR and RDP, by its strong emphasis on defined, and very specific growth-enhancing projects. It is important to note however, that in many senses, ASGISA is a continuation of GEAR (Bhorat and Van der Westhuizen, 2008). ASGISA originated from a commitment made by ANC in its 2004 election manifesto to halve unemployment and poverty by 2014. Accomplishing this depends on achieving 6\% growth per year by 2010. By 2004, economic growth had exceeded the average $3 \%$ growth per year of the first 10 years of democracy. Yet the challenge remained to increase and sustain growth at levels sufficient to meet social grants (ASGISA Annual Report, 2006). It targets massive expansion of infrastructure and skills: planned spending on infrastructure amounts to nearly five percent of GDP per annum over the next five years, with a parallel increase in the scale of human resources allocated to skills development and education. ASGI-SA aims to boost employment by prioritizing the tourism and business process outsourcing sectors, both labourintensive export sectors with opportunities for small and medium businesses (Gelb, 2007).

\subsection{New Growth Path}

There is growing consensus that creating decent work, reducing inequality and defeating poverty can only happen through a new growth path founded on a restructuring of the South African economy to improve its performance in terms of labour absorption as well as the composition and rate of growth. To achieve that step change in growth and transformation of economic conditions requires hard choices and a shared determination as South Africans to see it through. The government is committed to forging such a consensus and leading the way by identifying areas where employment is possible on a large scale as a result of substantial changes in conditions in South Africa and globally and developing a policy package to facilitate employment creation (New Growth Path, 2009).

\subsection{National Development Plan}

Achieving full employment, decent work and sustainable livelihoods is the only way to improve living standards and ensure a dignified existence for all South Africans. This will be achieved by expanding the economy to absorb labour and improving the ability of South Africa's people and institutions to respond to opportunities and challenges. The National Development Plan aims to reduce unemployment rate to 6 percent by 2030. To achieve full employment, the country needs to create about 11 million jobs in the next 20 years. The economy is expected to grow by about 5, 4 percent on average every year over this period to achieve this aim (National Development Plan, 2011).

\section{Literature Review on Macroeconomic Policies}

Nattrass (1998) found that according to GEAR, South Africa is pursuing a set of 'integrated', 'coherent' and 'technically sound' policies which add up to a consistent and investor-friendly framework. Labour-intensive growth is a central tenet of GEAR - as is greater labour market flexibility. He argues that although it was claimed that GEAR represented the government's integrated growth strategy, in reality it represented the vision of the Department of Finance and small band of economists. One of the problems in evaluating GEAR is that in some crucial respects it was neither implemented as proposed, nor was it as 'integrated' as its proponents claimed. The vision outlined in GEAR is very different to the 
policies followed by the Department of Labour.

Weeks (1999) states that the ANC government implemented an orthodox macroeconomic policy which stressed deficit reduction and a tight monetary policy, combined with trade liberalization. The stated purpose of GEAR was to increase economic growth, with a 4, $\%$ rate programmed for 1996-2000. At the mid-term of the programme, growth remained far below this target. The GEAR; s lack of success cannot be explained by unfavorable external factors; rather, disappointing performance seemed the result of fiscal contraction and excessively high interest rates.

Abedian (2005) in his retrospective analysis found that GEAR, as an integrated macroeconomic strategy, helped sustain private sector investment at a time when the public sector and its agencies were undergoing reconstruction and were unable to invest. Critically, by raising the economy's resilience GEAR enabled the economy to cope with ongoing global turbulence since 1996. As South Africa moved up the sovereign credit rating scale, the cost of borrowing in the global capital market declined steadily. Setting a new benchmark for South Africa's global creditworthiness had important socio-economic consequences. It reduced the cost of finance for government and improved government's ability to meet its service delivery obligations. Also the improved credit rating benefited the country's corporate sector, facilitating its ability to access international lines of credit and finance at declining costs.

Khamfula (2004) writes that the performance of GEAR has, to a great extent, also been dwarfed by the global economic crisis, which spread to South Africa in 1998. The decline in world demand for South Africa exports between 1995 and 2000, in general, brought about massive shedding of labour by South African firms. This was done in order for the firms to become competitive. He investigated whether economic policy currently employed in South Africa is consistent with the theoretical views of how policy would affect economic growth. He argues that the South African government is not doing enough to stimulate economic growth in the economy.

Seekings and Nattrass (2004) found that GEAR strategy failed to produce the envisaged results. The achievements were mainly on the stabilization side. Only two of the four major measures had been implemented: the reduction of the budget deficit and the liberalization of foreign trade, but not labour market reforms or privatization. The growth rate of 6 per cent per annum never materialized (Lundahl and Petersson, 2009).

Frankel, Smit and Sturzenegger (2006) suggest that ASGISA relies too heavily on capital accumulation, in a way that other growth accelerations have not. In addition there are grounds for doubt whether the required jump in investment will be forthcoming, and for worry by how much it would deteriorate South Africa's current account deficit. South Africa would suffer less from a sudden stop of capital inflows than would other emerging economies, particularly because most of the inflows do not take the form of debt denominated in foreign currency. Nevertheless, the already-large current account deficit is worrisome.

Fatas and Mihov (2009) look at recent empirical research that questions the conclusion that macroeconomic policy does not matter for growth. By looking at the volatility of economic policy (whether it is fiscal policy or exchange rates), we find that policy is still a relevant and robust explanatory variable of cross-country differences in economic growth. These results have strong policy implications. Improvements in the conduct of macroeconomic policy can have beneficial growth effects even if institutional reforms are not taking place. These results do not deny the importance of institutional reforms. By setting the right institutions one can ensure the proper conduct of macroeconomic policy without having to rely on the "quality" of the decision maker.

\section{Research Methodology}

\subsection{Study area}

A wealthy country by continental standards, South Africa is also one of the most unequal societies on earth (Marais, 2001). South Africa is often described as an engine of growth in Africa, in the sense that South African economic growth is believed to have a substantial impact on growth in other African countries. This view appears plausible because of South Africa's relatively large economic size and its growing linkages with other African economies (Arora and Vamvkides, 2005). South Africa compares well with middle-to-low income countries (Blankley and Booyens, 2010). Compared to other middle income economies, South Africa is highly urbanized (Lewis, 2001) and has a relatively strong average labour productivity but extremely low employment (OECD, 2011). In per capita terms South Africa is an uppermiddle-income country, but most South African households experience outright poverty or vulnerability to being poor. In addition, the distribution of income and wealth in South Africa is among the most unequal in the world (May, 2000). The dominating force in economic activity is the formal sector, which has a formidable manufacturing capacity by African standards (McCarthy, 2005). 


\section{Research Design}

Combining qualitative and quantitative research methods in a single study is widely practiced and accepted. There is a growing recognition of the benefits to be gained from combining quantitative and qualitative methods in a research. The best research design is a mixed method design that integrates qualitative and quantitative research. This type of design begins with a strong research methodology with quantitative methods that are enhanced with qualitative measures.

This is a correlational research and it does not fit neatly into the definition of either qualitative or quantitative research methodologies, but instead it utilizes elements of both. Correlation of economic growth and employment is a quantitative method of research. This study will determine the relationship between two variables.

Policy analysis is methodologically diverse using both qualitative and quantitative research methods. Qualitative research provides valuable information to certain research questions in its own right but there is a strong case for using it to complement quantitative methods.

\section{Data Collection}

The data used has been collected using three different methods over the period of 1994 to 2012, and these are October Household Survey (1994 to 1999), Labour Force Survey (2000 to 2007) and Quarterly Labour Force Survey (2008 to 2012).

The OHS is an annual survey, based on a probability sample of large number of households (30 000 in 1995, 16 000 in 1996, 30000 in 1997, 20000 in 1998 and 30000 in 1999). It covers a range of development and poverty indicators, including unemployment rates, according to standard definitions of the International Labour Organization, access to education and access to infrastructure (Stats SA, 2000).

The Labour Force Survey is a twice-yearly rotating panel household survey, specifically designed to measure the dynamics of employment and unemployment in the country. It measures a variety of issues related to the labour market, including unemployment rates, according to standard definitions of the International Labour Organization (ILO). A rotating panel sample involves visiting the sample dwelling units on a number of occasions (in this case, five at most), and after the panel is established, replacing a proportion of these dwelling units each round (in this instance 20\%). New dwelling units are added to the sample to replace those that are taken out. The advantage of this type of design is that it offers the ability to see how the work situation of members of the same dwelling units change over time, while retaining the large picture of the overall employment situation in the country (Stats SA, 2001).

The first LFS was conducted in 2000 and since then it has been undertaken on a six-monthly basis in March and September. Starting in 2005, Stats SA undertook a major revision of labour Force Survey (LFS). The revision resulted in changes to the survey methodology, the survey questionnaire, the frequency of data collection and data releases, and the survey data captures and processing systems. The redesigned labour force survey is Quarterly Labour Force Survey, which in now the principal vehicle for collecting labour market information on a quarterly basis (Stats SA, 2009).

The purpose of historical version is to make the September LFS estimates from 2001 to 2007 comparable with the QLFS data starting in 2008. Revising historical LFS data means that the revised LFS data for, say, September 2002 represent Stats SA's best estimate of what the QLFS would have shown had it been conducted in Q3, 2002 (Stats SA, 2009).

The Quarterly Labour Force Survey (QLFS) is a household-based sample survey conducted by Statistics South Africa (Stats SA). It collects data on the labour market activities of individuals aged 15 years and above who live in South Africa (Stats SA, 2012). This study used the revised LFS data and the QLFS.

\section{Data Analysis}

\subsection{Determining the relationship between economic growth and employment in South Africa}

Employment-related economic indicators, particularly those that measure the ability of economies to generate sufficient employment opportunities for their populations, often provide valuable insights into economies' overall macroeconomic performance. Among the most widely publicized indicators along these lines are unemployment rates, employment-topopulation ratios, and labour force participation rates. Another labour market indicator that, perhaps owing to its somewhat less accessible title, receives less attention in the literature is the employment intensity of growth, or elasticity of employment with respect to output. The most basic definition of this indicator is that it is a numerical measure of how 
employment varies with economic output - for instance, of how much employment growth is associated with one percentage point of economic growth (Kapsos, 2005). A valuable indicator for understanding the evolution of labour market outcomes is the elasticity of employment with respect to output. This indicator gives information on the employment intensity of growth and gives indication on how employment and GDP growth are correlated (IMF, 2012a).

Economic growth has a close connection with employment growth. It has been the focus of macroeconomic research in the field that how many impetuses economic growth give to employment growth. The essence of the problem is how to estimate employment elasticity accurately and reasonably (Wang, 2008). At present, there are three main methods of estimating employment elasticity in domestic and foreign research:

1. Estimating employment elasticity according to its definition. This method can obtain employment elasticity not only every year, but also a longer period. This method is simple, but lacks accuracy, because this prerequisite that the other factors of economic growth remain unchanged in the flexible definition, which is often difficult to meet.

2. Estimating employment elasticity of GDP by economic growth model, which is an indirect method of calculation. The advantages of this method lie in considering economic growth and technological progress, capital investment and labour inputs and other factors. The disadvantages lie in regarding employment variables as independent, and regarding GDP variables as dependent variables. According to the presupposition of the model, independent variables should be non-random variables, and attributive variable should be random variables. So the method confuses the cause and effect of the fact.

3. Estimating employment elasticity by dual-logarithm model. This method is simple and intuitive, and the assumption accords with the casual relationship, regarding GDP as independent variables and seeing employment as dependent variables. All other factors that are not considered are included in the constants. Employment elasticity estimating by this method is a constant. The model assumes that the economic structure for a period of time is not changed. But the assumption is usually difficult to meet.

As a result of changing data collection methods (from OHS to LFS and now QLFS), this study uses the first mentioned technique of calculating employment elasticity of economic growth. It makes it easier to make comparisons over the three periods.

The extent to which economic growth is associated with higher employment (total working hours) - the employment intensity of growth - can be depicted as the quotient of the rate of change in total hours worked and that of real GDP. It must be borne in mind that this relation is neither constant over time nor linear with respect to growth (EMU, 2001).

A concise measure of the relationship between employment and growth is the employment coefficient (E), defined here as the ratio of employment growth (e) to economic growth (g):

$\mathrm{E}=\mathrm{e} / \mathrm{g}$

$E$ is thus a measure of the responsiveness of employment to growth or employment elasticity. There may be periods when employment growth is faster than economic growth ( $E>1$, employment is elastic), and periods when employment growth is slower (but still positive) than economic growth ( $0<E<1$, employment is inelastic). There may also be periods when employment growth is zero or negative despite positive economic growth ( $E \leq 0$, zero or negative employment elasticity).

\subsection{Justification of GDP as a measure of economic growth}

One of the most important indicators, which reflect the performance of the national state's economy, is GDP. It is ranked among the most watched macroeconomic indicators (Hornungova and Klimkova, 2011). It is in many ways the central measure of an economy (Hobijin and Steindel, 2009). For example, the faster the growth in real GDP, the faster the growth is in jobs. The ability to forecast GDP, and to understand how policy influences the series, is therefore of critical importance to the formulation of monetary and fiscal policy. GDP, especially real GDP, is considered the central measure of overall economy activity primarily because its long- and short-run movements are correlated with many factors of interest to economists and policymakers alike. An important example is the close relationship over the long run between real GDP growth and the growth of real, or inflation-adjusted, income, and thus the improvement in living standards (Hobijn and Steindel, 2009). 


\section{Research Findings}

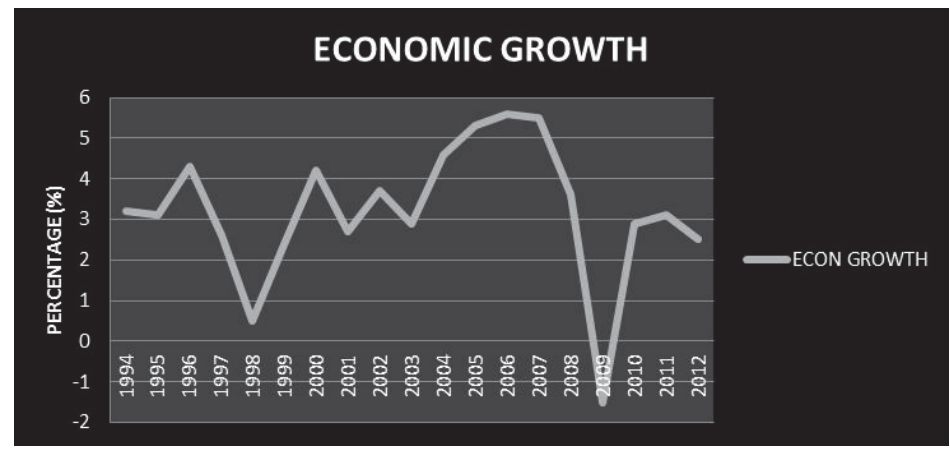

\section{Figure 1:}

The figure above depicts a very unstable economic growth from 1994, with two major downfalls experienced in 1997 to 1998 and also in 2008 to 2009. However, South Africa's economy has grown remarkably, especially from 2003 to just before the 2008/09 global recession. It has record the highest growth rate in 2007. It is believed that a number of factors have contributed to the positive performance of the country's economy. Bhorat and Cassim (2004) attributed that growth is dependent on a range of issues beyond macroeconomic stability, trade liberalization or labour market flexibility. Hanival and Maia (2008) describe Asian financial crisis as a major factor to have contributed the poor South African economic growth in 1998.

Like many other countries, South Africa was hard-hit by the global economic crisis, mainly through trade and financial channels (OECD, 2010), this largely explains the downwards trend between 2008 and 2009. It was the worst output decline in the post-apartheid era, and this according to OECD (2010) was larger than in most advanced and emerging economies, though far from being worst. A range of factors including gross imbalances and inequalities in the global economic system, the impact of financial of economies, ineffectual regulation in several of the major world economies and poor business practices are believed to have contributed to the global crisis according. The recession has been marked by a sharp drop in employment, sales, exports and capacity utilization in industry (RSA, 2009).

In successfully navigating the transition from apartheid to democracy, the government of South Africa has made impressive gains in stabilizing the economy and laying a firm foundation for higher economic growth and a broad-based improvement in living standards (Lundahl and Petersson, 2009). While South Africa's growth rate has risen, it is just too low to tackle unemployment. Progress has been made to get the economy on to a higher growth path. Government has now placed the creation of meaningful employment as a central pillar of economic policy (Baxter, 2011).

Like other developing countries which are strongly integrated into the world economy and significantly dependent on it for its good health, South Africa has been affected by the sharp fall in demand for its export products and the fall in prices of key export commodities. In addition, the international credit crisis has meant that funds have become scarce and expensive and that portfolio investors are wary of emerging markets, including South Africa. The impact of these developments has been significant on the local economy (RSA, 2009).

Brazil, Russia, India and South Africa (BRICs) are on the move with China destined to become the world's largest economy, possible as soon as 2030. Though small by the BRIC standard, China and Russia have invited South Africa to join the club. While the first decade of the new democracy saw South Africa firms enjoy limited competition in expanding into Africa they now find themselves in an encircling movement: Brazil from the West, Russia from the North, India and China to the East (Kahn, 2011).

An economy's growth rate is determined by the state of increase in the use of capital, labour and other factors of production, and the efficiency with which these factors are used. Economic growth is complex because of the vast range of subsidiary factors that influence these fundamental variables. These subsidiary factors include labour productivity, market structures, regulations and other microeconomic policies, economic growth in trading partners, and the macroeconomic management of the economy through business cycle (Faulkner and Loewald, 2008). 


\subsection{Employment analysis}

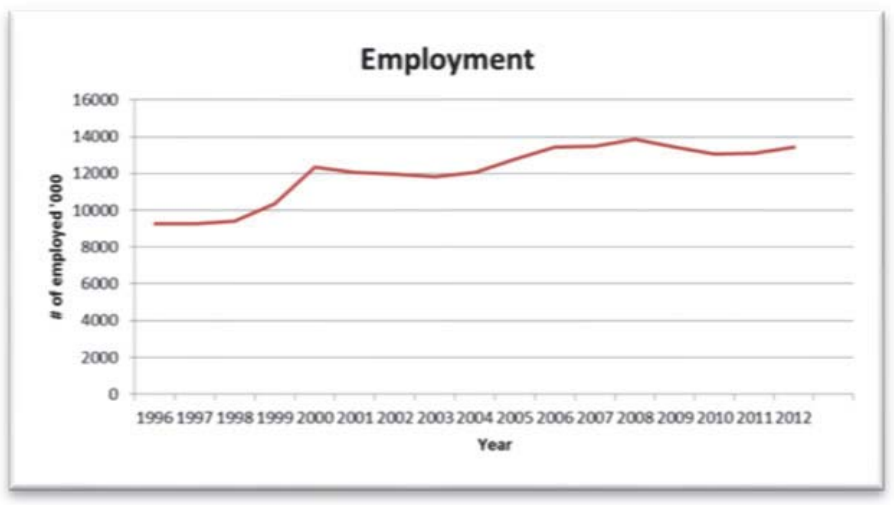

\section{Figure 2:}

The figure above depicts the total number of employed people in South Africa from 1996 to 2012. The curve shows a slight increase from 1996 to 2012. However, job creation has not been convincing. For a period close to 20 years, South Africa has failed to create just five million jobs. This makes it very unlikely to create eleven million jobs by 2030 as outlined in National Development Plan. South Africa has never had a stable or rather improving labour market in the post-apartheid era. Job creation has always been at the center of all macroeconomic policies implemented after 1994.

For the past three years, labour force has been declining. Labour force is the biggest source for prosperousness. However, as it is for each source, if the labour force is not correctly and appropriately used, it gives damage instead of providing a benefit. Correctly usage of labour force is possible with employment (Celik and Tatar, 2011).

Informal sector and manufacturing have been contributing largely to employment levels in South Africa.

\subsection{Unemployment analysis}

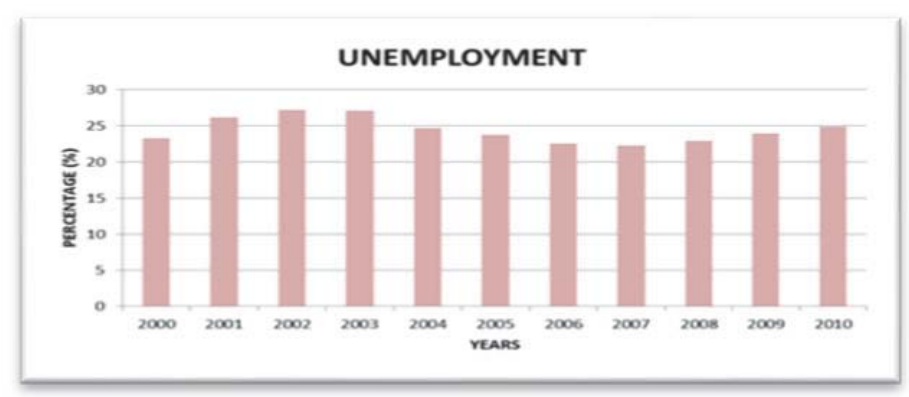

Figure 3:

It can be seen in figure 3 that since 2000 the unemployment rate has been ranging between 20 to $30 \%$ measured in a narrow definition. South Africa has experienced a rise in unemployment after 2007.

South Africa has one of the highest unemployment rates in the world (Burger and Fintel, 2009). The rise in unemployment started as early as the 1970s but continued and accelerated in the post-apartheid period.

South Africa's accelerated growth has been accompanied by an unresponsive labour market. According to University of Pretoria (2009), this is largely due to high levels of structural unemployment. Structural unemployment is defined as the unemployment caused by the mismatch of skills offered by the workforce and skills required of available vacancies. Economic growth since the end of apartheid has sharply increased demand for skilled labour, but the demand for semi-skilled and unskilled labour has if anything fallen, leaving overall employment unchanged (McCord, 2002) (ODI,2004). 


\subsection{Results from the Analysis}

High employment intensity indicates that growth in output leads to considerable job creation while low estimates of employment intensity suggest little correlation between economic growth and employment.

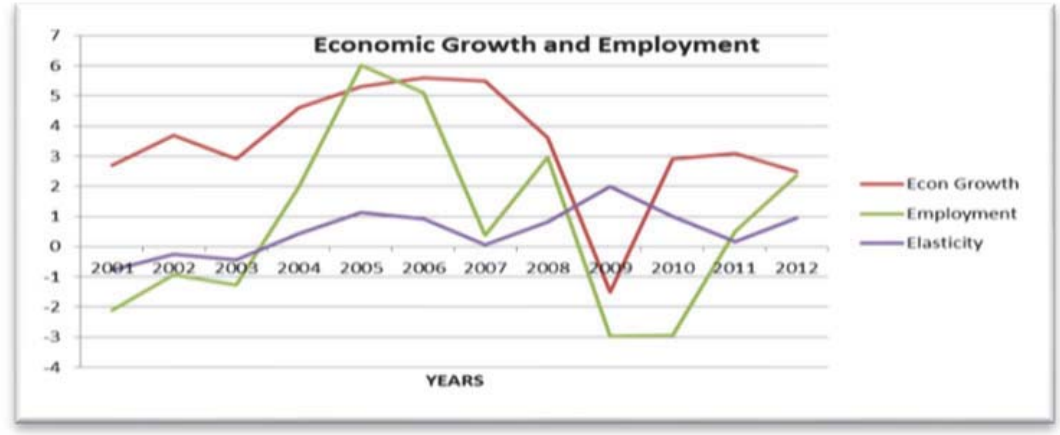

\section{Figure 4:}

The figure above indicates percentage changes in economic growth and employment. It also shows a curve of how responsive employment has been to economic growth. It is just a reflection of what is in a table below. However, the disadvantage of elasticity curve depicted in the figure above may confuse the true nature of the relationship. This may be true when both economic growth and employment declines. For example, in 2009, a decrease in economic growth rate has led to a fall in employment. The figure shows a correct positive elasticity which is not a true reflection of the relationship between economic growth and employment. The analysis takes little consideration of the above figure and focuses on the results in the table below. However, this does not mean the figure is of less importance at it provides a picture of economic growth and employment in percentage changes over the mentioned period.

Table 1:

\begin{tabular}{cccc}
\hline Year & Econ Growth & Employment & Elasticity \\
\hline 2001 & 2.7 & -2.1 & -0.78 \\
$\mathbf{2 0 0 2}$ & 3.7 & -0.93 & -0.25 \\
$\mathbf{2 0 0 3}$ & 2.9 & -1.27 & -0.44 \\
$\mathbf{2 0 0 4}$ & 4.6 & 1.96 & 0.43 \\
$\mathbf{2 0 0 5}$ & 5.3 & 6.01 & 1.13 \\
$\mathbf{2 0 0 6}$ & 5.6 & 5.1 & 0.91 \\
2007 & 5.5 & 0.37 & 0.07 \\
2008 & 3.6 & 2.95 & 0.82 \\
2009 & -1.5 & -2.97 & 1.98 \\
2010 & 2.9 & -2.93 & -1.01 \\
2011 & 3.1 & 0.5 & 0.16 \\
2012 & 2.5 & 2.35 & 0.94 \\
\hline
\end{tabular}

It can be seen that employment growth started to respond positively to economic growth after 2003. For most of ASGISA term, employment elasticity has been inelastic. This, however, does not mean that ASGISA's robust economic performance has not been accompanied by job creation. It implies that the increase in employment has been less responsive to the change in economic growth.

In interpreting the results from the above table, the last column (elasticity) shows how responsive employment has been to just one percentage point in economic growth.

The employment elasticity after the 2008/09 global recession proves to be enough evidence that, indeed, economic growth can be a mirror of employment levels in the country. However, the relationship between these two variables may differ from country to country, and may also be influenced by time periods and other factors.

Economists and politicians may have expected to see a booming economic recovery from apartheid and an elastic 
employment, thus every percentage change increase in economic growth accompanied by an increase in employment that is greater than one percent. In the beginning of 21st century, South Africa had a total of just over 12 million people employed. When one compares this with the total number of working people in 2012 of just close to 13,5 million, it really can be concluded that South Africa has failed to create sufficient jobs. For just over a decade, the country has failed to increase the total number of working population by 2 million. This possesses a huge threat to the health of the economy.

In a jobless growth economy, unemployment remains stubbornly high even as the economy grows. This tend to happen when a relatively large number of people have lost their jobs and the ensuing recovery is insufficient to absorb the unemployed, under-employed and new members entering the work force (Ajilore and Yinusa, 2011). It is true that people have lost their jobs in South Africa, like in any other country. Economic growth has not yielded the most desirable results as far as employment creation is concerned.

When the relationship between economic growth and employment is evaluated, the contribution of economic growth to employment in many countries is more slowly and so the fact that employment problem has been getting difficult is known (Akan, Arslan, Karatay and Druica, 2008). This is true in South Africa. A decline in economic growth rate in 2009 was accompanied by almost double of the percentage in employment. The results after 2000 show that South Africa has been characterized by inelastic and negative elastic employment intensity of growth. It is only in 2005 where a one percentage change in economic growth was accompanied by a little over a percentage change in employment.

Walterskirchen (1999) found that a higher growth of labour supply tends to raise employment and reduce productivity, thus suggesting a higher level of employment intensity of economic growth. Mourre (2006) found that employment intensity tends to be highest in the service sector, suggesting that nations with large service sectors should exhibit higher employment intensities (Seyfried, 2008).

A high unemployment rate has an effect similar to that of an increased labour supply. It tends to increase the employment intensity of growth, and it puts pressure on enterprises to raise employment, particularly in low-wage areas (Akan et. al, 2008).

Ensuring that growth is pro-poor requires high employment-intensity of growth and a rise in productivity which also depend on institutions, policies, laws and practices that positively affect the functioning of labour markets. A wellfunctioning institutional environment can support the virtuous circle and, in the process, facilitate pro-poor growth (Ernst and Berg, 2009).

The primary factor that may constraint employment creation is weak economic growth. Strong economic growth leads to continuous upward shifts in the long-run demand for labour curve leading to employment growth over the longterm (Sen and Kirkpatrick, 2009). The challenge facing South Africa is to lift economic growth significantly in a way that is employment creating and sustainable, which in turn, requires a continuous improvement in productivity performance (McCarthy, 2005).

The "Redistribution with Growth" and the "Basic Human Needs" schools argued that growth was not enough and that development ought to be equally concerned with poverty, income inequalities and employment (Ohiorhenuan, 2011).

Raising productivity requires improving human capital, increasing physical capital, or using these forms of capital more efficiently (Vietor and Weinzierl, 2012). South Africa has relied too heavily on physical capital.

One of the main problems of the national economies is their small capacity to generate employment under conditions of the existence of an economic growth process. The economic literature and practice proves the fact that a high rate of economic growth is a previous condition necessary for economic development, poverty reduction respectively, but the socio-economic impact of economic growth is different in terms of the effect that this growth has on employment (employment intensity of growth). Employment is considered a key mediator between economic growth and poverty reduction, being the one that makes the significant difference in terms of the impact of economic growth on human development (Herman, 2012).

\subsection{Policy Analysis}

The origins of post-apartheid policies are found in the 'economic crisis' which started during the 1970s, characterized by a structural slowdown in economic growth reinforced by political problems (Gelb, 2007). Inheriting an economy in disarray and faced with external pressures and questions over credibility, in 1994 the new government was forced to concentrate on macro policy concerns (Lewis, 2001). Following the policies implemented during the 1990s, the South African economy has become more globalized (Rangasamy and Blignaut, 2005). It appears that over the past 15 years, South Africa has successfully achieved a stable macro economy (Coulibaly and Logan, 2009).

Confronted by the legacy of past polices, South Africa's government has committed itself to correcting structural 
injustices and improving the living conditions of citizens (Yemek, 2006). The key debates after apartheid have been on the successes and shortcomings of the social and economic policies that were adopted after apartheid. The ANC government planned to provide services that would improve the poor lives and also create employment to sustain development (Batyi, 2009). Since the birth of South Africa's democracy, the government introduced a series of policies that were aimed primarily at creating an environment conducive to growth (Bhorat and Cassim, 2004).

Over the past three decades, the focus of macroeconomic policies, everywhere, has become narrower with the passage of time (Nayyar, 2011). In recent years, macroeconomic shocks leading to sharp reductions in employment and income have been observed in several developing countries. The manner in which households respond to such shocks and particularly the role and effectiveness of government responses to such shocks is an important public policy concern (Iturriza, Bedi and Sparrow, 2011).

From a policy perspective, employment depends on both economic growth and the labour-absorption capacity of the economy. Policy must target both these (Altman, 2003). The high rate of unemployment in South Africa stands out in an otherwise vastly improved set of macroeconomic fundamentals compared with the situation in the early 1990s (Hodge, 2009). Rising unemployment is a source of considerable concern to both policymakers and labour market participants (Burger and Von Fintel, 2009).

The challenge facing the new South African government is immense and from the perspective of policy formulation the government has responded in a credible fashion. From the perspective of implementation, however, current progress does not appear to have met either the expectations of policy makers or the poor (May, 2000). Traditionally, policy instruments used in market economies to deal with unemployment problems are macro-economic instruments like public expenditure, the marginal tax rate and the exchange rate or the official re-discount rate. International experience does not indicate the success of such passive policies in effectively controlling unemployment. This has led to a surge of interest in active labour market policies such as training, job creation and the promotion of counseling and placement services (OECD, 1994)(Xu and Bennington, 2008).

The government has carried out a series of market-friendly economic policies that have contributed to the increasing efficiency and productivity of the economy (Bhorat and Cassim, 2004). Economic policy has given overwhelming priority to financial policy instruments and objectives (exchange rates, interest rates) relative to concerns for the 'real' side variables and goals that directly affect employment and growth. Such shifts are not only reflective of the exigencies of adjustment to the economic crises that have ravaged Africa since the mid-1970s, but also of the increased presence of international financial institutions in African policy-making (Mkandawire,1999) (Heintz and Pollin, 2008).

The government outlined an ambitious but balanced economic reform program, called ASGISA, which was born from the ANC's commitment to halve unemployment and poverty by 2014 during the 2004 election (Dube, Hausmann and Rodrik, 2007). Before launching AsgiSA, there were two major development strategies since 1994. The first was the Reconstruction and Development Programme (RDP), which was part of the election platform of the African National Congress in 1994 elections. Its primary objective was to remove racial biases in a bid to address poverty and socioeconomic inequalities inherited from the previous regime. Government introduced a macroeconomic policy framework called the Growth, Employment and Redistribution (GEAR) strategy in 1996. It set a goal of achieving sustained annual real gross domestic product (GDP) growth of $6 \%$ or more by the year 2000 while creating 4000000 new jobs each year (Kearney and Odusola, 2011).

The key policy framework which has determined the trajectory of the post-apartheid economic transformation is the GEAR policy that the Department of Finance (now National Treasury) introduced in 1996 (Heintz, 2003). From a perspective of economic governance, shared growth can be perceived as a development strategy that sees poverty reduction and economic growth as interdependent goals over the medium to long term (Yemek, 2006).

Although South Africa has its economic fundamentals right, growth and employment creation have been limited owing to inherent policy instability, corruption, crime, weak public institutions and weak corporate governance (Bhorat and Cassim, 2004).

Investment in South Africa, as elsewhere, responds to the rate of return on capital and negatively to the real user cost of capital, thereby providing policy makers with some immediate policy levers. But a key determinant of investment appears to be uncertainty, especially uncertainty that arises from institutional constraints on economic performance (Fedderke, 2005).

Macroeconomic policies are neither formulated nor implemented in a vacuum. It is, therefore, important to recognize the significance of the political context. What governments can or cannot do in the sphere of macroeconomic policies is also shaped in the realm of politics (Nayyar, 2011). Political factors ranging from institutional governance to the construction of political coalitions in support of good polices plat an especially important role in economic growth 
(Faulkner and Loewald, 2008).

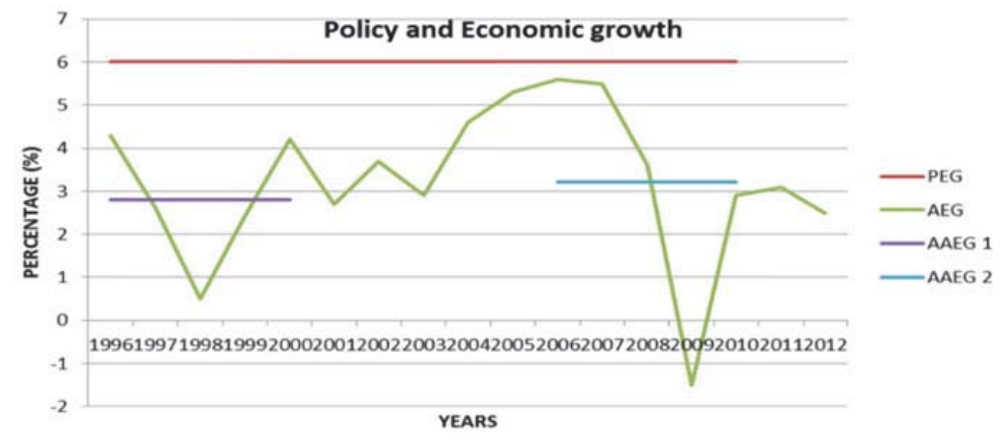

\section{Figure 5:}

The figure above shows projected economic growth (PEG), actual economic growth (AEG), average actual economic growth during GEAR (AAEG 1) and average actual economic growth during ASGISA (AAEG 2).

GEAR has failed to achieve its targeted average economic growth rate of $6 \%$ between 1996 and 2000. The average economic growth achieved in the mentioned period is a low $2.8 \%$. It has averaged to less than $50 \%$ of the targeted in the policy framework.

The successful political transition raised hopes for an economic transition characterized by broadly shared growth and greater access of the majority of the population to economic opportunities and, hence, jobs. Economic policies have, indeed, been gearing towards ensuring macroeconomic stability (with considerable success). However, the outcomes in terms of growth of per capita incomes and employment have been below expectations (Fedderke, 2005). This demonstrates that macro stability since 1994 has not been enough (Lewis, 2000). This may have contributed to the formulation of ASGISA.

ASGISA was adopted at the beginning of 2006 in the hope of ensuring that GEAR's positive economic growth could be "shared" by all South Africans (RSA, 2006) (Tsheola, 2012). According to the South African government, ASGISA is not a new economic policy, but rather an initiative comprising strategic interventions to counter the main constraints on economic growth (Yemek, 2006).

Little or no progress has been made by the government in an attempt to reduce unemployment. ASGISA had earlier targeted to reduce employment to $15 \%$ by 2014 . When it was adopted in 2006 , unemployment rate was at $22.6 \%$. It has been hovering at this rate until after the global recession in 2008 where it moved from $24 \%$ to $25 \%$ in 2010 . Until the adoption of the New Growth Path policy in 2009, it was very unlikely that ASGISA would achieve its targets in terms of economic growth and employment creation. One of the things ASGISA nearly got right is economic growth rate. It has average at 3.22\% from 2006 to 2010. Had it not been of the 2008 recession, South Africa would be having a robust economy.

Economic growth rate in 2008 was the worst for the country in its post-apartheid history. This recession dragged the economy to just $-1.5 \%$. With the recent economic growth pick up, it is still very unlikely whether employment would be responsive to this growth.

The ultimate objective of economic policy should be improvements in well-being and human development, as reflected in the MDGs (Heintz and Pollin, 2008).

According to COSATU (2011), the New Growth Path does not represent breakthrough in economic thinking and in economic policy. The policy instruments that it proposes are no different from those contained in GEAR, especially the development policy package.

If this appears to be true, the chances for the New Growth Path achieving its target are very slim. 


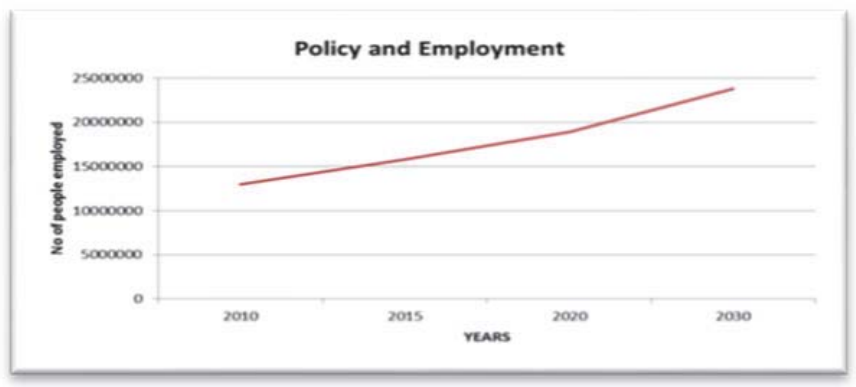

\section{Figure 6:}

An averaged economic growth increase of just $5.4 \%$ may not be enough to generate the projected jobs. South Africa is most likely to have another policy aimed at improving economic growth and creation of jobs in the next few years. National Development Plan policy was adopted while two other macroeconomic policies are still in place, although this is deemed a longer term policy. ASGISA and New Growth Path still have their targets for 2014 and 2020 respectively. To what extent this three policies influence each other remains unseen. However, the National Planning Commission (National Development Plan, 2011) believes a critical complementary between the New Growth Path and the National Development Plan is the need to lower costs in the economy, especially as these costs contribute towards limiting employment growth and raising costs for poor households. If this, really, is a case, the coordination of these policies may be a huge obstacle.

\section{Discussion}

The study determined the relationship between economic growth and employment from 1994 to 2012 in South Africa. It provided the analysis on both economic growth and employment for the mentioned period. It also provided an analysis on the performance of macroeconomic policies in terms of economic growth and employment targets.

An analysis of the relationship shows that South Africa has had a jobless growth. However, this does not mean that the country has failed to create jobs since the fall of the apartheid. The reality is that South Africa could not create sufficient jobs. The 1998 Asian Financial Crisis and 2008/09 Global Financial Crisis have worsened the situation.

The study further suggested areas that can stimulate job creation. It also showed that macroeconomic policies have improved the performance of the economy, but failed to create enough jobs.

It found that South African economy performance has been improving since the end of apartheid but it has, however, been very unstable. South Africa has enjoyed a good economic recovery since the fall of the apartheid, but economic growth rate figures have not surpassed the targeted ones as in the country's past macroeconomic policies.

The projected economic growth rates in the macroeconomic packages may not be enough to create sufficient jobs for the nation and thus lowering higher unemployment levels.

Major contributing areas to employment levels have been informal sector and manufacturing sector. South Africa is having a serious decline of jobs in agricultural sector. Two major post-apartheid crisis have tried to drag down South African economy, and these are 1998 Asian Financial Crisis and 2008/09 Global Financial Crisis. Had not they occurred, South Africa would be having a much improved economic performance. However, economic growth, alone, is not enough to rescue the country from job crisis it has been facing for over a decade.

The relationship between economic growth and employment has been unstable. For most part of the analysis, South Africa has had an inelastic employment elasticity of growth. Employment has been less responsive to changes in economic growth. Long period of negative elasticity was followed by longer period of inelastic employment intensity of growth. For a decade after democracy, South Africa only had one year where employment growth was very responsive to economic growth.

It is true that there exists a relationship between economic growth and employment. It is believed that this relationship can be influenced by other factors. It can be concluded that a higher economic growth can be accompanied by job creation in South Africa. Macroeconomics policies implemented after 1994 have improved economic growth but failed to meet employment targets. 


\section{Conclusions and Recommendations}

The study provided an analysis on both economic growth and employment. It also examined the employment and economic growth relationship in the South African economy by estimating the employment elasticity of growth.

The adoption of all the macroeconomic policy in the post-apartheid South Africa shows that government is trying to fight higher unemployment levels, but the results show that the government is far from winning the battle. The study agrees that high unemployment levels also have pre-apartheid macroeconomic policy roots. It is very difficult to estimate how long it may take South Africa to operate at near full employment.

South African economy has improved. The benefits of the improvement have gone to capital, not to labour. It is true because millions of the populations are still struggling to find jobs even after more than a decade of democracy. Economic growth has not translated in employment opportunities.

The recommendations are as follows:

It may take a few to many decades for South Africa to operate at full employment. South Africa needs to readjust its macroeconomic focus. New macroeconomic policies should take into account the country's increasing population and its impact on labour market. South Africa may need to readjust its macroeconomic focus to the one that largely targets social development. It can be seen that economic growth has not been enough to create sufficient jobs.

Fast growth in manufacturing output leads to fast growth in productivity outside of manufacturing. This occurs as manufacturing draws labour and other resources from non-manufacturing activities, without having a concomitant reduction in output in these other sectors. According to Millin and Nichola (2005), the degree to which this process takes place varies from economy to economy, but in a mature, industrialized economy, there may be little or no scope for such labour/resource transfer, which tends to slow growth in such an economy. This study sees that manufacturing sector should play an important role in driving the economy, given the large labour force and hence, the rising unemployment rate in the country.

Most analysts agree that political corruption and malgovernance are among the principal barriers to economic development and social betterment in the Third World (Kurtz and Schrank, 2007). Rising crime levels and corruption inhibit expansions of investment and employment (Schoeman and Blignaut, 1998; World Bank, 2006) (Mahadea, 2010). South Africa has higher levels of crime and corruption, the government needs to take stringent decisions against those who are on the other side of the law. Expanding investment will create more jobs. The study believes that high corruption levels in the country are hampering the process of creating jobs.

South Africa is moving away from a labour-intensive output growth path, as partly reflected in falling share of manufacturing employment and contribution to GDP and rising employment and output in the services sector (Mahadea and Simson, 2010). Its economy is one of the most capital intensive in the world (Coulibaly and Logan, 2009). Certainly there is evidence to suggest that human capital carries significance for growth in the South African economy (Fedderke, 2010). Higher human capital will allow the labour market to absorb a significant portion of the excess supply of labour (Coulibaly and Logan, 2009).

Achieving rapid growth over the medium term is not something that is tremendously difficult and it is well within most countries' reach (Hausmaan et al, 2005). South Africa needs to target a higher economic growth rate. Economic growth rate of $7 \%$ over a next few years may lower unemployment levels.

In Germany, the promotion of self-employment among the unemployed has become an increasingly important instrument of the active labour market policy. The principal idea of promoting self-employment among unemployed is to raise the employment level by helping the unemployed to create their own and preferably additional jobs (Quentier, 2012). Most of the structures and strategies of government to meet the challenge of job creation have been weak. South Africa needs to revisit its structures and strategies for self-employment. If self-employment is well-promoted, unemployment levels would significantly decrease.

The study recommends that the state should promote Public Private Partnership. This may help to stimulate job creation.

The main aim of the study was not to explore the factors affecting the relationship and to what extent they affect the relationship in South Africa. This remains a possible area of research.

\section{References}

Abedian, I. 2005. Towards a post-GEAR macroeconomic policy for South Africa. Trajectory for South Africa. Centre for policy studies. Johannesburg.

Accelerated Shared Growth Initiative for South Africa Annual Report. 2006. South Africa. 
Adelzadeh, A. 1996. From the RDP to GEAR: The gradual embracing of neo-liberalism in economic policy. Transformation 31.

Ajilore, T., and Yinusa, O. 2011. An analysis of employment intensity of sectorial output growth in Botswana. Southern African Business Review vol15:2.

Akan, Y., Arslan, I., Karatay, P., and Druica, E. 2008. Effects economic growth creates on employment in the knowledge society process (1980-2007) Universitatii Petril, Gaze din Ploiesti Vol LX: 3. Stinte Economice, Seria.

Altman, M. 2003. Jobless or job creating growth? Some Preliminary thoughts. Employment and Economic Policy Research Programme, Human Sciences Research Council.

Arora, V., and A. Vamvakides. 2005. Implications of South Africa's economic growth for the rest of Africa. SA Journal of economics Vol $73,2$.

Banerjee, A., Galiani, S., Levinsohn, J., McLaren, Z. and I. Woolard. 2006. Why has unemployment risen in the New South Africa? International Policy Center. Gerald R. Ford School of Public Policy. University of Michigan.

Baxter, R. 2011. Repositioning the South African Mining Industry for Sustainable Growth and Job Creation. Presentation to Portfolio Committee on Minerals, in Cape Town. Chamber of Mines of South Africa.

Batyi, T.T. 2009. The link between economic development programmes (RDP \& GEAR) and poverty reduction. Airport Valley as an illustrative case. Nelson Mandela University. South Africa.

Berument, H., Dogan, N. and Tansel, A. 2008. Macroeconomic policy and unemployment by economic activity: evidence from Turkey. Discussion Paper Series. IZA DP No. 3461.

Bhorat, H. and C. Van der Westhuizen. 2008. Economic Growth, Poverty and Inequality in South Africa: The First Decade of Democracy. Development Policy Research Unit, School of Economics. University of Cape Town.

Bhorat, H. and Cassim, R. 2004. The challenge of growth, employment and poverty in the South African economy since democracy: an exploratory review of selected issues. Development Southern Africa Vol. 21:1.

Blankley, W.O. and Booyens, I. 2010. Building a knowledge economy in South Africa. South African journal of economics Vol 106.

Bradford, C.I. 2005.Prioritizing economic growth: Enhancing macroeconomic policy choice. UN.

Burger, R. and Von Fintel, D. 2009. Determining the Causes of the Rising South African Unemployment Rate: An Age, Period and Generational Analysis. Working Paper Number 158. Stellenbosch University.

Celik, M., and Tatar, M. 2011. Employment-Unemployment Issues and Solution Suggestions: Adiyaman Example. Interdisciplinary Journal of Contemporary Research in Business, vol3:2.

Coulibaly, B., and D.T. Logan. 2009. South Africa's post-apartheid two-step: social demands versus macro stability. American economic review: papers and proceedings Vol 99:2.

Dube, O., Hausmann, R., and Rodrik, D. 2007. South Africa: Identifying the binding constraint on shared growth.

Du Plessis, S. and Smit, B. 2007. South Africa's growth revival after 1994. Stellenbosch economic working papers. University of Stellenbosch.

Dumitrescu, B. A., Dedu, V., and Enciu, A. 2009. The correlation between unemployment and real GDP growth. A case study on Romania.

Ernst, C., and Berg, J. 2009. The role of employment and labour markets in the fight against poverty. International Labour Organization.

Fatas, A and Mihov, L. 2009. Macroeconomic policy: Does it matter for growth? The role of volatility. The International Bank for Reconstruction and Development/ the World Bank on behalf of Commission on Growth and Development. Working Paper No.48.

Faulkner, D. and C. Loewald. 2008. Policy change and economic growth: a case study of South Africa. National Treasury of the Republic of South Africa, policy paper number 14.

Fedderke, J. 2005. Sources and Constraints of Long-Term Growth, 1970-2000. School of Economics and Centre for Social Science Research, University of Cape Town. South Africa.

Frankel, J., Smit, B. and F. Sturzenegger. 2006. South Africa: Macroeconomic challenges after a decade of success. Center for International Development at Harvard University.

Garett, A.T. and Rhine, R.M. 2010. Economic freedom and employment growth in U.S. States. Federal Reserve Bank of St Louis, Research Division.

Gelb, S. 2007. Macroeconomic policy in South Africa. From RDP through GEAR to ASGISA.

Heintz, J. and Pollin, R. 2008. Targeting employment expansion, economic growth and development in Sub-Saharan Africa. Outlines of an alternative economic programme for the region. Economic Commission for Africa.

Herman, E. 2012. The influence of the economic growth process on Romanian employment. University of Galati, Economics and Applied Informatics, XVIII: 1/2012.

Hobijn, B and Steindel, C. 2009. Do alternative measures of GDP affect its interpretation? Federal Reserve Bank of New York. Current issues in economics and finance, $\mathrm{Vol}$ 15:7.

Hodge, D. 2009. Growth, employment and unemployment in South Africa. South African journal of economics. Vol.77:4.

Hoogeveen, J.G. and B. Ozler. 2005. Not Separate, Not Equal: Poverty and Inequality in Post-Apartheid South Africa. William Davidson Institute Working Paper Number 739.

Hussain, M., Siddiqi, W. and Iqbal, A. 2010. A coherent relationship between economic growth and unemployment: empirical evidence from Pakistan. International journal of human and social sciences Vol 5:5.

IMF. 2012a. Unemployment and Labor Market Issues in Algeria, by D. Furceri. IMF working Paper, WP/12/99.

Iturriza, A., Bedi, A.S., and Sparrow, R. Unemployment Assistance and Transition to Employment in Argentina. University of Chicago.

Kahn, M. 2011. The fall of the wall, the rise of the BRICs and the new scramble for Africa. Foresight vol13:3. 
Kaspos, S. 2005. The employment intensity of growth: Trends and macroeconomic determinants. International Labour Office. Employment Trends Unit, Employment Strategy Department.

Kearney, M., and Odusola, A. 2011. Assessing Development Strategies to Achieve the MDGs in the Republic of South Africa. Realizing the Millennium Developmental Goals through socially inclusive macroeconomic policies. Country study. United Nations Department for Social and Economic affairs.

Khamfula, Y. 2004. Macroeconomic policies, shocks and economic growth in South Africa. School of Economic and Business Sciences. University of Witwatersrand. Johannesburg, South Africa.

Klein, N. 2011. Measuring the potential output of South Africa. International Monetary Fund, African Department.

Knight, R. 2006. South Africa 2006: Challenges for the future. South Africa delegation briefing paper.

Kurtz, J.M., and Schrank, A. 2007. Growth and Governance: Models, Measures, and Mechanisms. The Journal of Politics vol.69:2.

Lewis, J.D. 2001. Policies to promote growth and employment in South Africa, country director of South Africa. World Bank. 2001 annual forum at Misty hills, Mulders drift. Southern Africa department.

Lewis, J.D. 2002. Promoting growth and employment in South Africa. African region working paper series 32. World Bank. South African journal of economics vol70:4.

Lundahl, M. and L. Petersson. 2009. Post-apartheid South Africa, An economic success story? United Nations University, Research paper No. 2009/56.

Luyt, D. 2008. Governance, Accountability and Poverty Alleviation in South Africa. Center for social accountability. Switzerland.

Mahadea, D. and R. Simson. 2010. The challenge of "Low Employment Economic Growth" in South Africa: 1994 - 2008. School of economics and finance. University of KwaZulu natal.

Marais, H. 2001. South Africa- limit to change, The political economy of transition. University of Cape Town press. Cape Town.

May, J. 2000. Poverty and inequity in South Africa. Centre for Social and Development Studies, University of Natal.

Marh, P and L. Fourie. 2008. Economics for South African students. Juta. Cape Town.

Millin, M. and T. Nichola. 2005. Explaining economic growth in South Africa: a Kaldorian approach. International journal of technology management and sustainable development Vol 4:1.University of KwaZulu Natal.

National Development Plan. 2011. National Planning Commission. South Africa.

National Treasury. 2010. Transforming the South African economy. 2010 Budget review, South Africa.

National Treasury. 2011. 2011 Budget review. South Africa. Employment, chapter 3.

National Treasury. 2011. Confronting youth unemployment: Policy options for South Africa. Discussion paper for public comment.

Nattrass, N. 1998. Growth, employment and economic policy in South Africa: a critical review. Centre for Development and Enterprise.

Nayyar, D. 2011. Rethinking macroeconomic policies for development. Brazilian Journal of Political Economy, vol.31, 123. pp. 339-351.

ODI. 2004. Public works as a solution to unemployment in South Africa? Two different models of public works programme compared. ESAU Briefing Paper.

OECD. 2011. Growth, Employment and Inequality in Brazil, China, India and South Africa: An overview.

OECD. 2010. OECD Economic Surveys: South Africa.

Ohiorhenuan, J.F.E. 2011. The future of poverty and development in Africa. Foresight vol.13:3.

Phelps, M. 2008. Is there correlation between immigration, unemployment and GDP in America? Department of Economics, University of Akron Fall.

Quentier, J.M. 2012. Self-employment start-ups and value creation: An empirical analysis of German micro data. ACR vol20: 1 and 2.

Rangasamy, L. 2008. Exports and Economic Growth: The case of South Africa. Wiley InterScience (www.interscience. Wiley.com).

Rattso, J \& Stokke, E.H. 2007. A growth model for South Africa. South African Journal of Economics Vol. 75:4.

RSA. 2009. Framework for South Africa's Response to the International Economic Crisis. Republic of South Africa. www.gov.gov.za

Sen, K., and C. Kirkpatrick. 2009. A diagnostics approach to economic growth and employment policy in low income economies: The case of Kosovo. Wiley online Library.

Seyfried, W., and College, R. 2008. A Cross-Country Analysis of the Employment Intensity of Economic Growth. Rollins College. Southwest Business and Economics Journal.

Siphambe, H.P. 2007. Growth and Employment Dynamics in Botswana: A case study of policy coherence. Policy International and Statistics Department. International Labour Office, Geneva. Working Papers No. 82.

Sodipe, O.A. and Ogunrinola, O.I. 2011. Employment and Economic Growth Nexus in Nigeria. Department of Economics and Development Studies, Covenant University. Nigeria.

Stats SA. 2001. South African Statistics.

The New Growth Path. 2009. South Africa.

Todaro, M.P. 1992. Economics for a developing world: an introduction to principles, problems, and policies for development.

Tregenna, F. 2008. Which sectors can be engines of growth and employment in South Africa? An analysis of manufacturing and services. Faculty of economics, University of Cambridge Research Associate: HSRC.

Tsheola, J. 2012. The Binary Conception of Economics, Janus-Faced Development and the Aspiration for Accelerated and Shared Growth in South Africa. University of Limpopo. China-USA Business Review, Vol.11:2.

University of Pretoria. 2009. A Review of the South African Microfinance Sector. Volume 2. Background papers. South Africa.

Vietor, R.H.K., and Weinzierl, M. 2012. A reform fiscal policy is vital to renewing America's productivity. Here's a way forward. Macroeconomic policy and U.S. Competitiveness. Harvard Business Review.

Wang, Q. 2008. Economic growth and employment elasticity problems of Heilongjiang. School of Management, University of Mining and 
Technology, China.

Weeks, J. 1999. Suck in low GEAR? Macroeconomic policy in South Africa, 1996-98. Cambridge Journal of Economics, 23 795-811.

$\mathrm{Xu}, \mathrm{L}$., and Bennington, L. 2008. Xiagang and re-employment policies in Shangai. Management Research News, Vol31:12.

Yemek, E. 2006. Budgetary perspectives on shared growth policy initiatives in South Africa. Occasional Papers, IDASA - Africa Budget Unit. www.idasa.org.za 